\title{
INDEKS MASSA TUBUH DENGAN TEKANAN DARAH PADA MAHASISWA STIK SITI KHADIJAH PALEMBANG
}

\author{
M Ramadhani Firmansyah ${ }^{1}$, Septi Viantri Kurdaningsih ${ }^{2}$ \\ Dosen Prodi Ilmu Keperawatan STIK Siti Khadijah Palembang \\ Jalan Demang Lebar Daun Lorok Pakjo Palembang 30137 \\ Email :ramadhani2687@stik-sitikhadijah.ac.id
}

\begin{abstract}
Abstrak
Kegemukan dan obesitas saat remaja dapat menyebabkan berbagai penyakit metabolik degeneratif saat dewasa dan lansia.Penelitian ini bertujuan untuk mengetahui hubungan indeks massa tubuh dengan tekanan darah pada mahasiswa Program Studi Ilmu Keperawatan STIK Siti Khadijah Palembang Tahun 2019. Penelitian ini menggunakan desain penelitian kuantitatif dengan metode deskriptif analitik dengan pendekatan cross sectional, sampel penelitian ini adalah mahasiswa Program Studi Ilmu Keperawatan STIK Siti Khadijah Palembang, teknik pengambilan sampel dengan cara purposive sampling. Penelitian ini dilaksanakan pada tanggal 18 sampai dengan 23 November tahun 2019 dengan jumlah responden sebanyak 61 responden. Uji statistik yang digunakan adalah uji chi square. Dari uji statistik menunjukkan ada hubungan yang bermakna antara indeks massa tubuh dengan tekanan darah dengan nilai $p$ value $=0,001$. Diharapkan bagi peneliti selanjutnya dapat meneliti faktor atau variabel lainnya yang berhubungan dengan tekanan darah dengan metode yang berbeda dan sampel yang lebih besar.
\end{abstract}

\section{Kata Kunci: Indeks Massa Tubuh, Tekanan Darah}

\begin{abstract}
Overweight and obesity during adolescence could cause various degenerative metabolic diseases in adults and the elderly. This study aimed to determine the relationship between body mass index and blood pressure in students of the Nursing Study Program at STIK Siti Khadijah Palembang in 2019. This study used a quantitative research design with descriptive methods. analytic with a cross sectional approach, the sample of this research was the students of the Nursing Study Program at STIK Siti Khadijah Palembang, the sampling technique was purposive sampling. This research was conducted on 18 to 23 November 2019 with a total of 61 respondents. The statistical test used was the chi square test. The statistical test showed that there was a significant relationship between body mass index and blood pressure with a p value $=0.001$. It was hoped that the next researcher can examine other factors or variables related to blood pressure with different methods and larger samples.
\end{abstract}

Keywords : Body Mass Index, Blood Pressure. 


\section{PENDAHULUAN}

Kegemukan dan obesitas saat remaja dapat menyebabkan berbagai penyakit metabolik degeneratif saat dewasa dan lansia. Beberapa penyakit yang dapat disebabkan oleh kegemukan dan obesitas antara lain hipertensi, diabetes melitus, penyakit jantung koroner, dan gangguan pada tulang di masa yang akan datang. Selain itu, obesitas remaja juga dapat mempengaruhi produktivitas kerja (WHO, 2018).

Menurut data dari Riset Kesehatan Dasar (2018) bahwa jumlah obesitas pada remaja di Indonesia mengalami peningkatan. Pada tahun 2007 obesitas remaja sebanyak 18,8\% dan meningkat pada tahun 2013 menjadi 26,6\%. Pada tahun 2018 kembali terjadi peningkatan menjadi $31 \%$ (Kementerian Kesehatan Republik Indonesia, 2018).

Menurut data dari Riset Kesehatan Dasar (2018) bahwa angka kejadian hipertensi di Indonesia pada usia 18 tahun ke atas pada tahun 2018 sebesar 34,1\%. Angka tersebut mengalami peningkatan dari tahun 2013 sebesar $25,8 \%$. Prevalensi hipertensi pada usia 18 - 24 tahun sebesar 13,2\% (Kementerian Kesehatan Republik Indonesia, 2018).

Hasil penelitian yang dilakukan olehYusrizal dkk., (2016) bahwa hipertensi pada remaja berhubungan dengan IMT (Indeks Massa Tubuh). Kelebihan berat badan akan berisiko terjadinya hipertensi sebanyak lima kali lebih tinggi dibandingkan dengan berat badan normal.

Peningkatan berat badan (BB) sangat berpengaruh pada mekanisme timbulnya kejadian hipertensi pada orang yang obesitas akan tetapi mekanisme terjadinya hal tersebut belum dipahami secara jelas namun diduga pada orang yang obesitas terjadi peningkatan volume plasma dan curah jantung yang akan meningkatkan tekanan darah (Marlina, et., al, 2016).

IMT merupakan indikator yang dapat digunakan untuk mengukur lemak tubuh pada anak-anak dan remaja. Pengkategorian berat badan yang mengarah pada masalah kesehatan yang cukup murah dan mudah dilakukan yaitu dengan pengukuran IMT (Supariasa et al., (2012) dalam Siahaan (2020)). Leptin, insulin, asam lemak bebas serta obstructive sleep apnea yang meningkat pada anak dengan obesitas akan menyebabkan konstriksi dan aktifitas sistem saraf simpatis. Vasokonstriksi juga dapat disebabkan oleh resistensi insulin dan disfungsional endotelia. Peningkatan aktifitas saraf simpatis ginjal, resistensi insulin dan hiperaktifitas sistem renin angiotensin menjadikan reabsorbsi natrium pada ginjal meninggi. Faktor-faktor tersebut akan mengakibatkan terjadinya hipertensi (Pertiwi et al., 2017).

Perawat berperan penting terhadap remaja dengan kegemukan dan obesitas. Adapun peran perawat dalam memberikan edukasi kepada remaja seperti mahasiswa yaitu dengan menjaga pola makan dan aktivitas fisik teratur dengan menggunakan landasan model promosi kesehatan (Health Promotion Model). Health Promotion Model merupakan model bagi perawat untuk mengeksplorasi proses biopsikososial yang kompleks dimana memotivasi individu untuk berperilaku tertentu yang ditujukan untuk meningkatkan derajat kesehatannya (Tomey \& Alligood, 2006 dalam Khotimah, 2018).

Kegemukan dan obesitas saat remaja dapat menyebabkan berbagai penyakit metabolik degeneratif saat dewasa dan lansia. Beberapa penyakit yang dapat disebabkan oleh kegemukan dan obesitas antara lain hipertensi, diabetes melitus, penyakit jantung koroner, dan gangguan pada tulang di masa yang akan datang. Penelitian ini diharapkan mahasiswa Program Studi Ilmu Keperawatan STIK Siti Khadijah Palembang dapat menjaga berat badan yang ideal untuk mencegah terjadinya peningkatan tekanan darah. 


\section{Jenis Penelitian}

Penelitian merupakan penelitian kuantitatif. Desain penelitian yang digunakan adalah studi analisis deskriptif dengan pendekatan penelitian cross sectional.

\section{Waktu dan Tempat Penelitian}

Penelitian ini telah dilakukan pada bulan November 2019 bertempat di STIK Siti Khadijah Palembang.

\section{Prosedur}

Penelitian ini dilakukan setelah mendapatkan perizinan dari STIK Siti Khadijah Palembang selaku tempat penelitian. Kemudian dilakukan pengukuran tinggi dan berat badan dengan menggunakan media timbangan berat badan dan meteran, serta dilakukan pengukuran tekanan darah dengan menggunakan tensi meter. Setelah data dikumpulkan diolah dengan menggunakan program komputer.

\section{Target/ Subjek Penelitian}

Populasi subjek penelitian adalah keseluruhan objek penelitian atau objek yang diteliti (Notoatmodjo, 2012). Populasi dalam penelitian ini adalah seluruh mahasiswa Program Studi Ilmu Keperawatan STIK Siti Khadijah Palembang sebanyak 155 orang.

Sampel adalah sebagian dari keseluruhan objek yang diteliti dan dianggap mewakili seluruh populasi (Notoatmodjo, 2012). Teknik pengambilan sampel dalam penelitian ini adalah purposive sampling yaitu dengan cara memilih sampel antara populasi sesuai dengan kriteria penelitian (Nursalam, 2013). Sampel yang digunakan Mahasiswa Program Studi Ilmu Keperawatan sebanyak 61 orang dengan kriteria sebagai berikut:

Kriteria inklusi:

a. Bersedia menjadi responden

b. Mahasiswa berusia $>18$ tahun

Kriteria eksklusi:

Mahasiswa yang pada saat pengambilan data tidak hadir.

\section{Data, Intrumen, dan Teknik Pengumpulan Data}

Dalam penelitian ini peneliti menggunakan pengukur tinggi badan dan timbangan berat badan serta tensimeter yang dilakukan kepada responden, lalu dihitung indeks massa tubuh dan tekanan darah responden.

\section{Teknik Analisis Data}

Analisa data pada penelitian terbagi menjadi 2 yaitu analisa univariat untuk mendapatkan distribusi frekuensi dari masingmasing variable dan analisa bivariat dengan menggunakan uji chisquare untuk mengetahui adanya hubungan antara imt dan tekanan darah

\section{HASIL PENELITIAN}

1. Indeks Massa Tubuh

Distribusi frekuensi indeks masa tubuh dapat dilihat apada table 1

Tabel 1 Distribusi Frekuensi Indeks Massa Tubuh

\begin{tabular}{|c|c|c|}
\hline $\begin{array}{l}\text { Indeks Massa } \\
\text { Tubuh }\end{array}$ & $\mathrm{n}$ & $\%$ \\
\hline Kurus & 11 & 18.0 \\
\hline Normal & 33 & 54.1 \\
\hline Gemuk & 17 & 27.9 \\
\hline Total & 61 & 100.0 \\
\hline
\end{tabular}
menunjukkan bahwa responden dengan Indeks Massa Tubuh normal lebih banyak yaitu 33 responden $(54,1 \%)$ dibandingkan dengan Indeks Massa Tubuh Gemuk yaitu 17 responden $(27,1 \%)$ dan Indeks Massa Tubuh Kurus yaitu 11 responden (18\%). IMT atau indeks Quatelet merupakan salah satu bentuk pengukuran atau metode skrining yang digunakan untuk mengukur komposisi tubuh yang diukur dengan menggunakan berat badan dan tinggi badan yang kemudian diukur dengan rumus IMT.

Indeks massa tubuh atau Body Mass Index merupakan suatu ukuran yang dapat 
memperkirakan adipositas. Jaringan adipose merupakan masa tidak aktif sebagai tempat penyimpanan energi yang berperan dalam homeostasis energi dan metabolisme Prastia, 2019). Hasil penelitian ini menunjukkan bahwa sebagian besar responden memiliki indeks massa tubuh normal $(54,1 \%)$. Penelitian ini sejalan dengan penelitian Pratama, Christanto, \& Bebasari (2015) yang menunjukkan bahwa responden paling banyak memiliki indeks massa tubuh normal $(47,93 \%)$.

Hasil penelitian ini juga sejalan dengan penelitian yang dilakukan Kristantio, J. E., \& Halim, S. (2019) bahwa sebagian besar responden memiliki indeks massa tubuh normal (67\%). Seseorang yang memiliki gaya hidup kurang baik seperti kurangnya aktivitas fisik dan sering memakan makanan instan akan memicu terjadinya kegemukan dan obesitas. Selain itu, adanya smartphone yang memiliki banyak program dan hiburan seperti fitur belanja, transportasi, dan makanan secara online menyebabkan seseorang malas untuk beraktivitas yang memicu penambahan berat badan (Suryawan, 2018).

Berdasarkan teori dan penelitian terkait, peneliti berasumsi bahwa sebagian besar responden memiliki indeks massa tubuh yang normal, namun ada beberapa responden dengan indeks massa tubuh gemuk. Ada banyak faktor yang dapat mempengaruhi indeks massa tubuh. Faktor-faktor tersebut antara lain pemilihan makanan, pola makan, gaya hidup, dan aktivitas fisik berpengaruh terhadap penyimpanan dan metabolisme energi dalam tubuh.

\section{Tekanan Darah}

Distribusi frekuensi untuk tekanan darah dapat dilihat pada table 2

Tabel 2. Distribusi Frekuensi Tekanan Darah

\begin{tabular}{lcc}
\hline \multicolumn{1}{c}{ Tekanan Darah } & n & \% \\
\hline Normal & 42 & 68.9 \\
\hline Prehipertensi & 19 & 31.1 \\
\hline Total & $\mathbf{6 1}$ & $\mathbf{1 0 0 . 0}$ \\
\hline
\end{tabular}

Hasil penelitian pada table 2 menunjukkan bahwa responden dengan tekanan darah normal lebih banyak yaitu 42 responden $(68,9 \%)$ dibandingkan dengan tekanan darah prehipertensi yaitu 19 responden (31,1\%). Hasil penelitian menunjukkan bahwa tekanan darah responden sebagian besar normal $(68,9 \%)$.

Hasil penelitian ini sejalan dengan penelitian yang dilakukan oleh Prastia (2019) bahwa sebagian besar responden memiliki tekanan darah normal $(66,1 \%)$. Penelitian Abaa, Polii, \& Wowor (2017) juga menunjukkan bahwa tekanan darah pada mahasiswa kedokteran umum angkatan 2014 mayoritas normal $(85,4 \%)$.

Tekanan darah dapat dipengaruhi oleh banyak faktor. Adapun faktor-faktor tersebut antara lain riwayat keluarga, indeks massa tubuh, jenis kelamin, konsumsi natrium yang berlebih, merokok, stres, tingkat ekonomi, dan sedentary lifestyle (Suryawan, 2018).

Berdasarkan teori dan penelitian terkait, peneliti berasumsi pada penelitian ini tekanan darah responden sebagian besar normal, namun responden yang ada pada kategori prehipertensi cukup tinggi $(31,1 \%)$. Hal ini perlu diperhatikan karena jika seseorang memiliki risiko untuk hipertensi maka harus mengubah pola hidupnya, meningkatkan aktivitas fisik, untuk mencegah terjadinya peningkatan tekanan darah.

\section{Hubungan Indeks Massa Tubuh dengan Tekanan Darah}

Analisis hubungan anatara indeks massa tubuh dengan tekanan darah dapat dilihat pada table 3 . Tabel 3. Hubungan Indeks Massa Tubuh
dengan Tekanan Darah 


\begin{tabular}{|c|c|c|c|c|c|c|c|}
\hline \multirow{3}{*}{$\begin{array}{c}\text { Indeks Massa } \\
\text { Tubuh }\end{array}$} & \multicolumn{4}{|c|}{ Tekanan Darah } & \multirow{2}{*}{\multicolumn{2}{|c|}{ Jumlah }} & \multirow{3}{*}{$\rho$ Value } \\
\hline & \multicolumn{2}{|c|}{ Normal } & \multicolumn{2}{|c|}{ Prehipertensi } & & & \\
\hline & $\mathbf{n}$ & $\%$ & $\mathbf{n}$ & $\%$ & n & $\%$ & \\
\hline Kurus & 8 & 72,7 & 3 & 27,3 & 11 & 100 & \\
\hline Normal & 30 & 90,9 & 3 & 9,1 & 33 & 100 & \\
\hline Gemuk & 4 & 23,5 & 13 & 76,5 & 17 & 100 & 01 \\
\hline total & 42 & & 19 & & 61 & 100 & \\
\hline
\end{tabular}

Hasil penelitian pada table 3 menunjukkan bahwa indeks massa tubuh normal dengan tekanan darah normal sebanyak 30 responden $(90,9 \%)$ lebih banyak dibandingkan dengan indeks massa tubuh kurus dengan tekanan darah normal sebanyak 8 responden $(72,7 \%)$ dan indeks massa tubuh gemuk dengan tekanan darah normal sebanyal 4 responden $(23,5 \%)$. Dari hasil uji Chi Square didapatkan $\rho$ value $0,001<\alpha(0,05)$ yang artinya ada hubungan yang bermakna antara indeks massa tubuh dengan tekanan darah pada mahasiswa Program Studi Ilmu Keperawatan STIK Siti Khadijah Palembang Tahun 2019.

Salah satu faktor yang mempengaruhi peningkatan tekanan darah atau terjadinya hipertensi adalah obesitas. Pada saat ini, kegemukan dan obesitas sering dijumpai baik pada anak - anak, remaja, hingga dewasa. Banyaknya aktivitas yang sedentari dengan banyak bermain video game pada smartphone, sering bermalas-malasan di rumah dapat meningkatkan kenaikan indeks massa tubuh sehingga berpengaruh pada kesehatan terutama tekanan darah (Mar'ah, 2017).

Hasil penelitian ini sejalan dengan penelitian Kristantio (2019) yang menunjukkan nilai $\mathrm{p}=0,005(<0,05)$ yang menunjukkan adanya hubungan yang bermakna antara indeks massa tubuh dengan tekanan darah pada mahasiswa Fakultas Kedokteran Universitas Tarumanagara. Penelitian yang dilakukan Marlina (2016) juga menunjukkan adanya hubungan indeks massa tubuh dengan tekanan darah.

Indeks massa tubuh yang berlebih memicu kenaikan tekanan darah. Peningkatan indeks massa tubuh menandakan adanya lemak berlebih di dalam tubuh, yang bisa mempengaruhi tekanan darah melalui sistem saraf simpatis - sistem renin angiotensin dan inflamasi vaskular. Jaringan adiposa merupakan tempat penyimpanan energi dalam bentuk lemak. Jaringan ini yang mengandung lemak dengan sifat yang aterogenik (kolesterol total, pecahan lipoprotein, dan trigliserida) memicu inflamasi vaskular dengan menginduksi pelepasan sitokin, faktor transkripsi proinflamasi, dan molekul adesi. Inflamasi yang berlangsung kronik sering dihubungkan dengan peningkatan tekanan darah yang dikategorikan dalam sindroma metabolik, yaitu peningkatan tekanan darah sistolik sama atau melebihi $130 \mathrm{mmHg}$ dan atau tekanan darah diastolik sama atau melebihi 85 mmHg (Kristantio et. al., 2019)

Penumpukan lemak dalam jaringan dinding pembuluh darah juga bisa menyebabkan terjadinya aterosklerosis jika terjadi disfungsi endotel. Penebalan dan pengerasan dinding pembuluh darah arteri akan terjadi dengan adanya plak atero sehingga bisa mengganggu fungsi endotel pembuluh darah dan menyumbat lubang pembuluh darah (penyempitan pembuluh darah pada bagian yang tersumbat) sehingga aliran darah menjadi terhambat. Penyempitan ini akan meningkatkan total peripheral resistance (TPR) yang bisa lebih meningkatkan tekanan darah secara perlahan (Sherwood, 2016).

Berdasarkan teori dan penelitian terkait, peneliti berasumsi bahwa tekanan darah dan indeks massa tubuh merupakan hal yang perlu diperhatikan karena merupakan risiko terjadinya penyakit degeneratif. Mahasiswa dengan indeks massa tubuh yang meningkat berpotensi untuk menderita hipertensi karena pembuluh darah arteri maupun vena dipenuhi oleh lemak sehingga menyebabkan tekanan darah meningkat .

\section{KESIMPULAN}

Berdasarkan uraian hasil penelitian dan pembahasan sebelumnya, maka peneliti memberikan beberapa kesimpulan yang dapat diuraikan sebagai berikut: 
1. Hasil penelitian menunjukkan bahwa mahasiswa dengan Indeks Massa Tubuh normal lebih banyak yaitu 33 responden $(54,1 \%)$ dibandingkan dengan Indeks Massa Tubuh Gemuk yaitu 17 responden $(27,1 \%)$ dan Indeks Massa Tubuh Kurus yaitu 11 responden (18\%).

2. Hasil penelitian menunjukkan bahwa mahasiswa dengan tekanan darah normal lebih banyak yaitu 42 responden $(68,9 \%)$ dibandingkan dengan tekanan darah prehipertensi yaitu 19 responden $(31,1 \%)$.

3. Hasil penelitian menunjukkan bahwa $\rho$ value $0,001<\alpha(0,05)$ yang artinya ada hubungan yang bermakna antara indeks massa tubuh dengan tekanan darah pada mahasiswa Program Studi Ilmu Keperawatan STIK Siti Khadijah Palembang Tahun 2019.

\section{SARAN}

\section{Bagi Peneliti Selanjutnya}

Diharapkan bagi peneliti selanjutnya dapat meneliti faktor atau variabel lainnya yang berhubungan dengan tekanan darah dengan metode yang berbeda dan sampel yang lebih besar.

\section{Bagi Institusi}

Diharapkan hasil penelitian ini dapat menjadi tambahan referensi bagi dosen dan mahasiswa tentang pentingnya menjaga indeks massa tubuh yang normal untuk mencegah terjadinya peningkatan tekanan darah.

\section{UCAPAN TERIMAKASIH}

Penulis mengucapkan terima kasih kepada seluruh pihak yang terkait yang telah membantu pelaksanaan penelitian ini.

\section{DAFTAR PUSTAKA}

Abaa, Y. P., Polii, H., \& Wowor, P. M. (2017). Gambaran Tekanan Darah, Indeks Massa Tubuh, dan Aktivitas Fisik pada Mahasiswa Kedokteran Umum Angkatan Tahun 2014. eBiomedik, 5(2).

Kementerian Kesehatan Republik Indonesia. 2018. Laporan hasil riset kesehatan dasar nasional tahun 2018. Jakarta: Balitbangkes depkes RI; 2018.

Khotimah, n. k. (2018). Model Peningkatan Kepatuhan Gaya Hidup Sehat Pada Pasien Hipertensi Berbasis Social Cognitive Theory Di Wilayah Kerja Puskesmas Kota BIMA (Doctoral dissertation, Universitas Airlangga).

Kristantio, J. E., \& Halim, S. (2019). Hubungan indeks massa tubuh dengan tekanan darah pada mahasiswa Fakultas Kedokteran Universitas Tarumanagara 2017. Tarumanagara Medical Journal, 2(1), 59-64.

Mar'ah. 2017. Hubungan Sedentary Life Dengan Kejadian Obesitas Pada Anak Di Sdn Mangkura 1 Makassar.

Marlina, Y., Huryati, E. and Soenarto, Y., 2016. Indeks massa tubuh dan aktivitas fisik dengan tekanan darah pada pelajar SMA. Jurnal Gizi Klinik Indonesia, 12(4), pp.160-166.

Obesity and overweight [Internet]. World Health Organization. 2016 [cited 7 November 2019]. Available at: http://www.who.int/mediacentre/factshee ts/fs311/en/.

Pertiwi, M., Susanti, E. W., \& Sunarti, S. (2017). Hubungan Obesitas dengan Hipertensi Esensial pada Pasien di Wilayah Kerja PUSKESMAS Karang Asam Tahun 2017.

Pramono A, Sulchan M. 2014. Kontribusi Makanan Jajanan dan Aktifitas Fisik terhadap kejadian obesitas pada remaja di Kota Semarang. jurnal gizi indonesia ;37(2):129-36.

Prastia, T. N. (2019). Gambaran Tekanan Darah Dan Indeks Massa Tubuh Pada Mahasiswa Prodi Kesmas Angkatan 2017 
Fikes Uika Bogor Tahun 2018. Promotor, 2(3), 234-239.

Sherwood L. Human Physiology from Cells to Systems. 9th ed. Canada: Cengage Learning; 2016. p. 340-342.

Siahaan, j. a. e. (2020). Hubungan Indeks Massa Tubuh (Imt) Dengan Tekanan Darah Pada Penderita Hipertensi Di Puskesmas Pancur Batu Tahun 2019.

Suryawan, Z. F. (2018). Analisis Faktor Yang Berhubungan Dengan Hipertensi Pada Remaja (Doctoral dissertation, Universitas Airlangga).

WHO. 2018. Global Health Estimates 2016: Deaths by Cause, Age, Sex, by Country and by Region, 2000-2016. Geneva: World Health Organization

Yusrizal, M., Indarto, D., \& Akhyar, M. (2016). Risk of Hypertension in adolescents with over nutritional status in Pangkalpinang, Indonesia. Journal of Epidemiology and Public Health, 1(1), 27-36. 